\title{
Genetic differentiation of Slovenian sweet potato varieties (Ipomoea batatas) and effect of different growing media on their agronomic and nutritional traits
}

\author{
Lovro Sinkovič, ${ }^{1}$ Barbara Pipan, ${ }^{1}$ Vladimir Meglič, ${ }^{1}$ Nataša Kunstelj, ${ }^{2}$ Marijan Nečemer, ${ }^{3}$ \\ Emil Zlatić, ${ }^{4}$ Dragan Žnidarčič ${ }^{5}$ \\ ${ }^{1}$ Crop Science Department, Agricultural Institute of Slovenia, Ljubljana; ${ }^{2}$ Biotechnical Centre Naklo, \\ Naklo; ${ }^{3}$ Department of Low and Medium Energy Physics, Jožef Stefan Institute, Ljubljana; ${ }^{4}$ Department of \\ Food Science and Technology, Biotechnical Faculty, University of Ljubljana, Ljubljana; ${ }^{5}$ Department of \\ Agronomy, Biotechnical Faculty, University of Ljubljana, Ljubljana, Slovenia
}

\begin{abstract}
The objectives of the present study were firstly to analyse the genetic relatedness among three Slovenian sweet potato varieties; and secondly to assess the effects of different growing media on selected agronomic and nutritional traits of these varieties. Tubers of three varieties (Lučka, Janja, Martina) with different skin/flesh colour were produced in planters under glasshouse conditions in five different growing media (perlite, peat, expanded clay, vermiculite, garden soil) from prior raised seedlings. Genetic analysis was performed using a set of eight single sequence repeats markers. According to Nei's genetic distance and pairwise population Fst analysis, the most related varieties are Janja and Martina; in contrast, Lučka and Martina show the weakest genetic relationships. The following agronomic traits were evaluated: vine length, thickness of vine-base, number of branches, weight of above ground part, number of leaves plant ${ }^{-1}$, number of tubers plant ${ }^{-1}$ and tubers weight plant ${ }^{-1}$. Between nutritional traits total phenolic content (TPC), antioxidant potential (AOP) and ascorbic acid content (AA) were determined in the range: 36.2 to $65.1 \mathrm{mg}$ gallic acid equivalent $100 \mathrm{~g}^{-1}$ fresh weight, 0.18 to $0.56 \mathrm{mg}$ Trolox equivalents $\mathrm{g}^{-1} \mathrm{FW}$

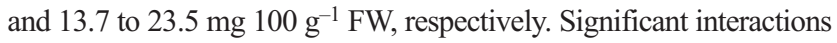
of growing media (factor A) $\times$ variety $($ factor $\mathrm{B})$ were observed for
\end{abstract}

Correspondence: Dragan Žnidarčič, Department of Agronomy, Biotechnical Faculty, University of Ljubljana, Jamnikarjeva 101, SI1000 Ljubljana, Slovenia.

Tel: +38613203227 - Fax: +38614231088.

E-mail: dragan.znidarcic@bf.uni-lj.si

Key words: Growing media; Genetic analysis; Ipomoea batatas; Phenolic compounds.

Received for publication: 28 February 2017.

Revision received: 9 May 2017.

Accepted for publication: 10 May 2017.

CC Copyright L. Sinkovič et al., 2017

Licensee PAGEPress, Italy

Italian Journal of Agronomy 2017; 12:949

doi:10.4081/ija.2017.949

This article is distributed under the terms of the Creative Commons Attribution Noncommercial License (by-nc 4.0) which permits any noncommercial use, distribution, and reproduction in any medium, provided the original author(s) and source are credited. thickness of vine-base, weight of above ground part, AOP, TPC and AA. Overall, results showed variation in varieties response to growing media. Growing media provide a discriminant classification of the sweet potato varieties according to their agronomic and nutritional traits.

\section{Introduction}

Sweet potato (Ipomoea batatas L.; Convolvulaceae) is ranking as the world's $7^{\text {th }}$ major food crop, which serves as an energy and phytochemical source of nutrition in more than 100 countries (FAOSTAT, 2017; Shekhar et al., 2015). The origin of sweet potato is Central America, but at present it is widely cultivated in the tropics and subtropics, and even in some temperate areas at different ecological regions (Chandrasekara and Kumar, 2016). In Europe, where the total production of sweet potato accounted $45.901 \mathrm{t}$ in 2014, the biggest producers are Portugal (22.591 t), Spain (13.550 t), Italy (6723 t) and Greece (3038 t) (FAOSTAT, 2017). In Slovenia, sweet potato has been quite unknown crop until recently, both for production and human consumption. The environment diversity and specific climatic conditions of this region could enable successful production of that crop in the future (Kunstelj et al., 2013, 2015). Three new Slovenian sweet potato varieties (Lučka, Janja, Martina) were registered in 2015 and are now added to national list of varieties (National list of Varieties, 2016).

Tubers of sweet potato are rich in dietary fibre, minerals, vitamins and antioxidants, such as phenolic compounds (Lebot et al., 2016; Tang et al., 2015; Teow et al., 2007). Besides acting as antioxidants, phenolic compounds and carotenoids also provide sweet potatoes with their distinctive flesh/skin colours (cream, deep yellow, orange, purple) (Ray et al., 2012). Contribution of sweet potato towards health is acknowledged due to high nutrient content and its anti-carcinogenic and cardiovascular disease preventing properties (Chandrasekara and Kumar, 2016; Jung et al., 2011). In recent years, several reports have indicated that the phytochemicals from sweet potatoes displayed antioxidative or radical-scavenging activity with health-promoting functions (Bovell-Benjamin, 2007; Teow et al., 2007; Rumbaoa et al., 2009). Phenolic acids (i.e., chlorogenic and dicaffeoylquinic acids) contribute to antioxidant activity and other health-beneficial properties of colour-fleshed genotypes (Oki et al., 2002; Padda and Picha, 2008). Additionally, cultivars with the same flesh colour may differ in total phenolic content, individual phenolic acid profile, and antioxidant activity.

Sweet potato readily produces adventitious roots and has trailing vines, therefore can colonise marginal soils and is not very demanding 
as regards soil type (Mukhtar et al., 2010). The most innovative technology of plant cultivation in greenhouse conditions is growing in mineral substrates such as rockwool, vermiculite, perlite, zeolite, expanded clay and others. The origin of substrates is different and they also differ in their physical, chemical, and biological properties. Peat and its mixes with perlite, vermiculite or zeolite are the most widely used substrates in greenhouse conditions (Jankauskiene et al., 2015). To the best of our knowledge there is no scientific literature regarding cultivation of sweet potato in different growing media.

Application of short sequence repeats (SSR markers) in genetic diversity studies of different agro-economically important species represents informative, effective and reliable marker system (Rusjan et al., 2012, 2015; Pipan et al., 2011, 2013, 2016; Maras et al., 2015; Derlink et al., 2014) for distinguishing among different genetic resources. For sweet potato, which is a hexaploid $(2 \mathrm{n}=6 \mathrm{x}=90)$ plant species with an out-crossing mating system (Veasey et al., 2008), SSR marker system is highly applicable due its codominant nature (Pipan et al., 2016).

The objective of the study was to analyse the genetic relatedness among three Slovenian sweet potato varieties, to examine the effect of different growing media on selected agronomic and nutritional traits of these varieties and to compare responses among varieties.

\section{Materials and methods}

\section{Plant material and growing media}

The experiment was carried out at the Glasshouse experimental station $\left(46^{\circ} 04^{\prime} \mathrm{N}, 14^{\circ} 31^{\prime} \mathrm{W}\right.$; altitude $310 \mathrm{~m}$ a.s.l.) of the Biotechnical Faculty in Ljubljana, Slovenia. Three new Slovenian varieties of sweet potato (Ipomoea batatas L.) were studied: Lučka with orange skin and flesh colour, Janja with white skin and flesh colour and Martina purple skin and white flesh colour. Cuttings and seedlings were grown in styrofoam seed starting trays filled with substrate for seedlings Neuhaus N3 (Humko, Slovenia) and covered with vermiculite.

Polypropylene troughs (Mapal Plastic Agricultural Products Division, Israel) were placed on parallel beds. Each of three troughs blocks ( $18 \mathrm{~m}$ length, $0.5 \mathrm{~m}$ width and $0.2 \mathrm{~m}$ height) was divided to plots, separated with polystyrene dams to avoid stirring and filled with growing media. In each plot two seedlings of individual variety were planted. The randomised complete block design (RCBD) was split plot with growing media applied to whole plots and varieties applied to split plots. The experiment was designed to test two factors: different growing media (factor A; perlite, peat, expanded clay, vermiculite, garden soil) and different sweet potato varieties (factor B). After the initial watering of the substrate and seedlings, T-tape tubes (T-Tape ${ }^{\circledR}$ TSX 500 Model) were placed over the growing media. Basic fertilisation was performed with water-soluble NPK fertiliser Entec Perfect (14-7-17, EuroChem Agro, Mannheim, Germany; $350 \mathrm{~kg} \mathrm{ha}^{-1}$ ) during planting of seedlings in growing media in the beginning of June. Two weeks after transplantation and throughout the growing period, the plants were fertilised three times per week with nutrient solution prepared with tap water containing water soluble NPK fertiliser Polifid (16-8-32, Haifa, Israel; $1 \mathrm{~g} \mathrm{~L}^{-1}$ ). During the growth period the following measures were implemented: removing weeds, monitoring the functioning of the irrigation system, cleaning dead plant parts and monitoring the presence of pests and diseases. At harvest, after 128 days growing period, the following agronomic traits were evaluated for individual variety and growing media: vine length $(\mathrm{cm})$, thickness of vine-base $(\mathrm{mm})$, number of branches, weight of above ground part ( $\mathrm{g}$ ), number of leaves plant $^{-1}$, number of tubers plant ${ }^{-1}$ and tubers weight plant ${ }^{-1}(\mathrm{~kg})$. For the analysis of total phenolic content (TPC), antioxidant potential (AOP) and ascorbic acid content (AA), random tubers of each variety and growing media were used. For the sample extraction, $8 \mathrm{~g}$ of fresh tuber slices (flesh and skin) were mixed with $10 \mathrm{~g}$ of $2 \%$ metaphosphoric acid dissolved in distilled water. The tissue was homogenised using an Ultraturax T 25 (20,500 rpm). Homogenised samples were centrifuged and filtered through a $0.45 \mu \mathrm{m}$ filters (17 mm syringe filter $\mathrm{CA})$. The extracts were stored at $-80^{\circ} \mathrm{C}$ until analysed.

\section{Genetic analysis}

Genomic DNA was extracted from frozen leaves of six different plants collected individually from each of three varieties grown in garden soil. BioSprint 15 DNA Plant Kit (Qiagen, Hilden, Germany) and MagMax (Applied Biosystems, Foster City, CA, USA) nucleic acids isolation robot, following the modified method from manufacturer's instructions, were used. Dilutions of $1 \mathrm{ng} \mu \mathrm{L}^{-1}$ of DNA were used for PCR amplification. Eight primer pairs: Ib-316, Ib-318, Ib-242, Ib-248, Ib-255F1, Ib-255, Ib-286 and Ib-297 (Buteler et al., 1999; Veasey et al., 2008) were applied for SSR assessment. PCR reactions were performed in a final volume of $11 \mu \mathrm{L}$, containing $1 \mathrm{ng}$ of genomic DNA and following reagents with starting concentrations of: $10 \times$ PCR buffer (Biotools, Madrid, Spain), $10 \mathrm{mM}$ of each dNTP's, $50 \mathrm{mM}$ $\mathrm{MgCl}_{2}$ (Biotools), $10 \mu \mathrm{M}$ of each primer, $10 \mu \mathrm{M} 5$ ' fluorescently labelled universal primer (6-FAM, NED, HEX) and 0.5 U of Taq DNA polymerase (Biotools). The forward primer of each SSR was appended with 18 bp tail sequence 5'-TGTAAAACGACGGCCAGT-3' (M13(21)) as described by Schuelke (2000). PCR analyses were performed on ABI 9700 (Applied Biosystems) under the following touch-down conditions: $94^{\circ} \mathrm{C}$ for $4 \mathrm{~min}$, thirty cycles at $94^{\circ} \mathrm{C}$ for $1 \mathrm{~min}$, auto increment temperature from $49.5^{\circ} \mathrm{C}$ for $0.5^{\circ} \mathrm{C}$ per cycle for $30 \mathrm{~s}, 72^{\circ} \mathrm{C}$ for 1 min, followed by thirty cycles at $94^{\circ} \mathrm{C}$ for $30 \mathrm{~s}$, auto increment temperature from $49.5^{\circ} \mathrm{C}$ for $0.5^{\circ} \mathrm{C}$ per cycle for $30 \mathrm{~s}, 72^{\circ} \mathrm{C}$ for $1 \mathrm{~min}$ and final extension for $5 \mathrm{~min}$ at $72^{\circ} \mathrm{C}$. Fragment analysis was performed on 3130XL Genetic Analyser (Applied Biosystems), the allele lengths were determined by comparison with size standard GeneScan-350 ROX (Applied Biosystems) using GeneMapper 4.0 (Applied Biosystems). Parameters of genetic diversity among loci and varieties, including number of migrants (Nm), inbreeding coefficients (Fst), \% of polymorphic loci, numbers of effective alleles, total expected heterozygosities $(H t)$, Shannon's information index, pairwise Nei's genetic correlations, pairwise population Fst analysis, analysis of molecular variance via R-statistics under 999 permutations (AMOVA) and principal coordinate analysis (PCoA) were conducted applying GenAlEx v.6.4 (Peakall and Smouse, 2006). Genetic differentiation regarding to Gst calculations were performed in Genetix 4.02 (Belkhir et al., 1999). Nei's standard genetic distance-Ds (1972) was computed from allele frequencies with using unweighted pair group method with arithmetic mean (UPGMA) algorithm in Populations software (Langella, 2002) by bootstrapping 100 times. The tree of genetic distances was constructed using TreeView (Page, 1996).

\section{Analysis of nutritional traits}

Analyses of bioactive compounds included evaluation of TPC, AOP and AA in tubers of sweet potato. The TPC was determined in triplicates using the Folin-Ciocalteu method, as described by Singleton and Rossi (1965), and slightly modified (Roura et al., 2006). Gallic acid (Merck, Germany) was used for six-point calibration curve, which ranged from $3 \mathrm{mg} \mathrm{L}^{-1}$ to $150 \mathrm{mg} \mathrm{L}^{-1}\left(\mathrm{R}^{2}=0.9998\right)$. The results were expressed as gallic acid equivalents [mg GAE 100 $\mathrm{g}^{-1}$ fresh weight $\left.(\mathrm{FW})\right]$. The AOP was evaluated in triplicates using the DPPH (2,2-diphenyl-1-picrylhydrazyl; Sigma-Aldrich, Saint Louis, MO, USA) free radical scavenging method (Nakajima et al., 2004). Trolox (Sigma-Aldrich) was used for six point calibration 
curve, which ranged from $40 \mathrm{mg} \mathrm{L}^{-1}$ to $220 \mathrm{mg} \mathrm{L}^{-1}\left(\mathrm{R}^{2}=0.9900\right)$. The results were expressed as Trolox equivalents ( $\left.\mathrm{mg} \mathrm{TE}^{-1} \mathrm{FW}\right)$. AA content was determined according to the method described by Quirós et al. (2009). AA analysis was performed in triplicates on an HPLC system (Agilent 1260; Agilent Technologies, Santa Clara, CA, USA) using a diode array detector, with the wavelength set at $254 \mathrm{~nm}$. The determination of AA was carried out on a $100 \times 2 \mathrm{~mm}$ i.d., $3 \mu \mathrm{m}$ Scherzo SM-C18 column (Imtakt, Portland, OR, USA), at a flow rate of $0.3 \mathrm{~mL} \mathrm{~min}{ }^{-1}$. The mobile phase consisted of water (A) and acetonitrile (B), both of which contained $0.3 \%$ formic acid. The following elution gradient was used for solvent B: $0-3 \mathrm{~min}, 0 \%-10 \%$; 3-4 $\min , 10 \%-100 \%$; 4-6 $\mathrm{min}, 100 \%$. The temperature of the column was maintained at $30^{\circ} \mathrm{C}$, while the temperature of the automatic sample feeder was set at $4^{\circ} \mathrm{C}$. AA was calculated using an external standard method and expressed as mg $100 \mathrm{~g}^{-1} \mathrm{FW}$.

\section{Statistical analyses}

Statistical analyses were performed using the Centurion Statgraphics XVI statistical analysis program. Prior statistical analyses data was tested for normal distribution using Shapiro-Wilk test. If the data was not normally distributed, log transformation was used prior further analysis. Multifactorial ANOVA analysis was used to determine statistical significance of main factors and interaction of sweet potato varieties with the growing media. The model was specified in GLM according to split plot experimental design. When ANOVA showed statistical significances, means were separated using Tukey's HSD test $(\mathrm{P}<0.05)$. Multivariate analysis was carried out using the XLSTAT software package. For determination of key traits responsible for discrimination based on differences in growing media for all sweet potato samples and differences according to sweet potato variety, the multivariate analysis by discriminant analysis was used.

\section{Results and discussion}

\section{Genetic differentiation}

SSR screening of sweet potato varieties was performed on 8 loci ( $91.7 \%$ polymorphic loci) where the highest levels $(\mathrm{Ht}>0.65)$ of genetic differentiation were assigned to loci Ib-318, Ib-297, Ib-248, Ib-242 and $\mathrm{Ib}-286$. Locus Ib-255 reflected the lowest informativity through low Ht (0.278), high inbreeding coefficient $(\mathrm{Fst}=0.400)$ and the lowest number of genetic migrants $(\mathrm{Nm}=0.375)$, detected among genotypes (Table 1). According to parameters of genetic diversity for specific loci, described in Table 1, the most effective genetic differentiation was obtained for locus Ib-286, where the lowest proportion of total genetic diversity that separates varieties was calculated via Fst (0.082) and the highest number of genetic migrants among genotypes and varieties $(\mathrm{Nm}=2.813)$ was detected.

AMOVA was performed through $\mathrm{R}$-statistics ( $\mathrm{P} \geq 0.01$ ), where Rst is an estimator of genetic differentiation for SSR loci that assumes a stepwise mutation model. Therefore, molecular variance between varieties was $36 \%$, between genotypes $63 \%$ and within genotypes $1 \%$, respectively. In contrast, report about evaluation of genetic variability of sweet potato germplasm, originated from Africa, Asia and USA shows only $23 \%$ of genetic variance among different accessions (Pipan et al., 2017). Therefore, our study indicates the low level of genetic relatedness between varieties Lučka, Janja and Martina compared to the genetic relatedness between different genetic resources from geographically distant genetic origins. First three axes in PCoA cumulatively explain $76.2 \%$ of genetic variation within observed genotypes and varieties (data not shown). Allelic patterns across three sweet potato varieties (Table 2) showed that the most genetically diverse variety is Martina. Meanwhile, variety Lučka possess the highest number of alleles that are unique and specific for this variety only (Table 2). The total genetic differentiation level among varieties regarding to Gst calculations was 0.144 (data not shown). According to Nei's genetic distance and pairwise population Fst analysis, the most related varieties are Janja and Martina; in contrast, Lučka and Martina show the weakest genetic linkages (Table 3). On Figure 1, the genetic relationships among varieties (on the basis of allele frequencies) are presented regarding to Nei's standard genetic distance and UPGMA clustering method.

\section{Agronomic and nutritional traits}

Table 4 shows the summary statistics of main factors and interactions and Table 5 the data of investigated agronomic and nutritional traits from different growing media for individual variety of sweet potato. For easier interpretation the Tables 4 and 5 show the untransformed data. Measurements of agronomic traits (Table 4) showed that between growing media (factor A) vermiculite had the greatest impact on the vine length $(144.4 \mathrm{~cm})$, although differences were not significant. Among sweet potato varieties (factor B) significantly longer vine length was observed for Lučka $(147.1 \mathrm{~cm})$. For thickness of vine-base differences were not significant either for growing media or variety. Number of branches was significantly higher for sweet potatoes grown in peat (13.0), while among varieties Martina (11.2) and Janja (10.6) had significantly more branches than Lučka. Both, growing media and variety, had significant impact on weight of above ground part. The weight of above ground part was significantly higher for sweet potato grown in peat (1402.4 g). Variety Martina produced significantly higher weight of above ground part (1242.2 g), i.e. more than double as Lučka (463.7 g). Significantly higher number of leaves plant ${ }^{-1}$ was observed for Martina (118.4), and between growing media in peat (131.1) and perlite (123.9). Both yield components, number of tubers

Table 1. Descriptive statistics among applied short sequence repeats loci in three sweet potato varieties.

\begin{tabular}{lccc} 
Locus & Ht & Fst & Nm \\
Ib-242 & 0.705 & 0.099 & 2.288 \\
Ib-248 & 0.753 & 0.171 & 1.216 \\
\hline Ib-255F1 & 0.674 & 0.165 & 1.266 \\
Ib-255 & 0.278 & 0.400 & 0.375 \\
\hline Ib-286 & 0.681 & 0.082 & 2.813 \\
Ib-297 & 0.736 & 0.108 & 2.054 \\
\hline Ib-316 & 0.586 & 0.179 & 1.147 \\
Ib-318 & 0.757 & 0.146 & 1.466 \\
\hline Mean & 0.646 & 0.169 & 1.578 \\
\hline
\end{tabular}

$\mathrm{Ht}$, total expected heterozygosity; Fst, inbreeding coefficient; $\mathrm{Nm}$, number of migrants.

Table 2. Allelic patterns according to genetic analysis across observed sweet potato varieties.

\begin{tabular}{lccc} 
& Janja & Martina & Lučka \\
Different alleles with a frequency $>=5 \%$ (n) & 3.000 & 3.250 & 2.250 \\
Effective alleles (n) & 2.692 & 2.758 & 2.158 \\
\hline Shannon's information index & 0.956 & 1.040 & 0.729 \\
Private alleles (n) & 0.375 & 0.500 & 0.750 \\
\hline Expected heterozygosity & 0.559 & 0.610 & 0.481 \\
\hline
\end{tabular}


plant $^{-1}$ and tubers weight plant $^{-1}$, were the lowest for sweet potatoes grown in garden soil. Comparison among varieties showed that Janja had the highest yield. Mukhtar et al. (2010) reported similar findings for vine length, number of branches and number of leaves plant ${ }^{-1}$ when tested two local sweet potato varieties with orange and white flesh.

Analyses of nutritional traits included TPC, AOP and AA of tubers. Data showed significant differences $(\mathrm{P} \leq 0.001)$ among the growing media and the varieties in all three traits (Table 4). The TPC ranged from 36.2 to $65.1 \mathrm{mg}$ GAE $100 \mathrm{~g}^{-1} \mathrm{FW}$, AOP from 0.18 to $0.60 \mathrm{mg}$

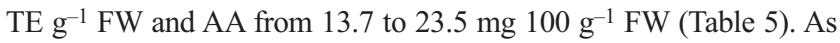
seen in Table 4 significantly higher TPC was found for sweet potatoes grown in perlite, expanded clay, vermiculite and garden soil (for all $>$

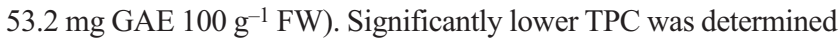
in peat (41.2 mg GAE $100 \mathrm{~g}^{-1} \mathrm{FW}$ ). Among varieties significantly higher TPC was observed in Lučka, i.e. $60.1 \mathrm{mg}$ GAE $100 \mathrm{~g}^{-1} \mathrm{FW}$ (Table 4). Variety Lučka with orange flesh colour showed significantly higher TPC compared to the other two white flesh coloured vari- eties, which is in agreement with previous studies on other varieties (Shekhar et al., 2015; Tang et al., 2015; Suárez et al., 2016). Similarly to TPC, significantly higher AOP was found for sweet potatoes grown in perlite, expanded clay and vermiculite (for all $>0.44 \mathrm{mg} \mathrm{TE} \mathrm{g}^{-1} \mathrm{FW}$; Table 4). Tubers of varieties Lučka and Martina had significantly higher AOP, 0.45 and $0.43 \mathrm{mg} \mathrm{TE} \mathrm{g}^{-1} \mathrm{FW}$, respectively. These results are lower as reported by Tang et al. (2015)

Table 3. Pairwise population comparisons of Nei genetic identity (below diagonal) and pairwise population inbreeding coefficient values (above diagonal).

Janja Martina Lučka

\begin{tabular}{lccc} 
Janja & $*$ & 0.072 & 0.148 \\
Martina & 0.829 & $*$ & 0.153 \\
\hline Lučka & 0.626 & 0.608 & $*$ \\
\hline
\end{tabular}

${ }^{*} \mathrm{P} \leq 0.05$.

Table 4. Statistics of main factors and interactions for investigated agronomic and nutritional traits of sweet potato.

\begin{tabular}{|c|c|c|c|c|c|c|c|c|}
\hline $\begin{array}{l}\text { Vine } \\
\text { length } \\
(\mathrm{cm})\end{array}$ & $\begin{array}{c}\text { Thickness of } \\
\text { vine-base } \\
(\mathrm{mm})\end{array}$ & $\begin{array}{l}\text { Branches } \\
\text { (n) }\end{array}$ & $\begin{array}{l}\text { Weight of above } \\
\text { ground part } \\
\text { (g) }\end{array}$ & $\begin{array}{l}\text { Leaves } \\
\text { plant }^{-1} \\
\text { (n) }\end{array}$ & $\begin{array}{l}\text { Tubers } \\
\text { plant }^{-1} \\
\text { (n) }\end{array}$ & $\begin{array}{l}\text { Tubers } \\
\text { weight } \\
\text { plant }^{-1}(\mathrm{~g})\end{array}$ & $\begin{array}{c}\text { TPC } \\
\text { (mg GAE } \\
\left.100 \mathrm{~g}^{-1} \mathrm{FW}\right)\end{array}$ & $\begin{array}{c}\text { AOP } \\
(\mathrm{mg} \text { TE } \\
\left.\mathrm{g}^{-1} \mathrm{FW}\right)\end{array}$ \\
\hline
\end{tabular}

Factor A

(growing media)

\begin{tabular}{|c|c|c|c|c|c|c|c|c|c|c|}
\hline Perlite & 107.3 & 6.9 & $8.6^{a b}$ & $7246^{b}$ & $123 \mathrm{ga}$ & $158^{\mathrm{a}}$ & $9822^{\mathrm{ab}}$ & $541^{\mathrm{a}}$ & $050^{\mathrm{a}}$ & $197 \mathrm{a}$ \\
\hline Peat & 129.8 & 9.3 & $13.0^{\mathrm{a}}$ & $1402.4^{\mathrm{a}}$ & $131.1^{\mathrm{a}}$ & $11.0^{\mathrm{a}}$ & $1517.6^{\mathrm{a}}$ & $41.2^{\mathrm{b}}$ & $0.32^{c}$ & $16.7^{\mathrm{b}}$ \\
\hline Expanded clay & 133.8 & 10.7 & $11.0^{\mathrm{ab}}$ & $934.9^{b}$ & $91.1^{\mathrm{ab}}$ & $14.1^{\mathrm{a}}$ & $1198.6^{\mathrm{a}}$ & $54.5^{\mathrm{a}}$ & $0.44^{\mathrm{ab}}$ & $16.6^{\mathrm{c}}$ \\
\hline Vermiculite & 144.4 & 9.3 & $9.9^{\mathrm{ab}}$ & $663.9^{\mathrm{b}}$ & $68.0^{\mathrm{b}}$ & $14.8^{\mathrm{a}}$ & $1358.3^{\mathrm{a}}$ & $53.2^{\mathrm{a}}$ & $0.44^{\mathrm{ab}}$ & $16.2^{\mathrm{e}}$ \\
\hline Garden soil & 130.3 & 8.5 & $6.0^{\mathrm{b}}$ & $239.3^{c}$ & $40.3^{c}$ & $6.6^{\mathrm{b}}$ & $324.4^{b}$ & $54.5^{\mathrm{a}}$ & $0.3 b^{b c}$ & $16.3^{\mathrm{d}}$ \\
\hline$P$ & ns & ns & $*$ & $* * *$ & $* * *$ & $* *$ & $* *$ & $* * *$ & $* * *$ & $* * *$ \\
\hline \multicolumn{11}{|l|}{ ictor B (variety) } \\
\hline Janja & $119.5^{b}$ & 9.3 & $10.6^{\mathrm{a}}$ & $740.0^{\mathrm{b}}$ & $90.6^{\mathrm{ab}}$ & 14.9 & 1168.0 & $46.0^{c}$ & $0.37^{\mathrm{b}}$ & $15.9^{\mathrm{b}}$ \\
\hline Lučka & $147.1^{\mathrm{a}}$ & 8.5 & $7.6^{\mathrm{b}}$ & $463.7^{c}$ & $68.9^{\mathrm{b}}$ & 10.1 & 976.7 & $60.1^{\mathrm{a}}$ & $0.45^{\mathrm{a}}$ & $20.4^{\mathrm{a}}$ \\
\hline Martina & $123.0^{\mathrm{b}}$ & 9.1 & $11.2^{\mathrm{a}}$ & $1242.2^{\mathrm{a}}$ & $118.4^{\mathrm{a}}$ & 12.7 & 1138.1 & $48.0^{b}$ & $0.43^{\mathrm{a}}$ & $14.9^{c}$ \\
\hline$P$ & $* *$ & ns & $*$ & *** & $*$ & ns & $\mathrm{ns}$ & $* * *$ & $* * *$ & *** \\
\hline
\end{tabular}

Interactions

$\begin{array}{lllllll}\mathrm{A} \times \mathrm{B} & \mathrm{ns} & * & \mathrm{~ns} & \mathrm{~ns} & \mathrm{~ns} & \mathrm{~ns}\end{array}$

TPC, total phenolic content; GAE, gallic acid equivalents; FW, fresh weight; AOP, antioxidant potential; TE, Trolox equivalents; AA, ascorbic acid content. ${ }^{\text {a-e }}$ Mean values with different letters in a column are significantly different according to the results of Tukey's honest significant difference test $(\mathrm{P}<0.05) .{ }^{* * *} \mathrm{P} \leq 0.001 ;{ }^{* *} \mathrm{P} \leq 0.01 ;{ }^{*} \mathrm{P} \leq 0.05$; ns, not significant.

Table 5. Data of investigated agronomic and nutritional traits from different growing media for individual variety of sweet potato.

\begin{tabular}{|c|c|c|c|c|c|c|c|c|c|c|c|}
\hline $\begin{array}{l}\text { Factor A } \\
\text { (growing } \\
\text { media) }\end{array}$ & $\begin{array}{c}\text { Factor } \\
\text { B } \\
\text { (variety) }\end{array}$ & $\begin{array}{l}\text { Vine } \\
\text { length } \\
\text { (cm) }\end{array}$ & $\begin{array}{l}\text { Thickness of } \\
\text { vine-base } \\
\text { (mm) }\end{array}$ & Branches & $\begin{array}{l}\text { Weight of above } \\
\text { ground part } \\
\text { (g) }\end{array}$ & $\begin{array}{l}\text { Leaves } \\
\text { plant }^{-1} \\
\text { (n) }\end{array}$ & $\begin{array}{c}\text { Tubers } \\
\text { plant }^{-1} \\
\text { (n) }\end{array}$ & $\begin{array}{l}\text { Tubers } \\
\text { weight } \\
\text { plant }^{-1}(\mathrm{~g})\end{array}$ & $\begin{array}{c}\text { TPC } \\
(\mathrm{mg} \mathrm{GAE} \\
\left.100 \mathrm{~g}^{-1} \mathrm{FW}\right)\end{array}$ & $\begin{array}{c}\text { AOP } \\
(\mathrm{mg} \mathrm{TE} \\
\left.\mathrm{g}^{-1} \mathrm{FW}\right)\end{array}$ & $\begin{array}{c}\mathrm{AA} \\
(\mathrm{mg} 100 \\
\left.\mathrm{g}^{-1} \mathrm{FW}\right)\end{array}$ \\
\hline erlite & Lučka & $6.0 \pm 22.3$ & $7.0 \pm 1.0$ & $6.3 \pm 3.5$ & $224.7 \pm 42.1$ & $80.7 \pm 21.5$ & $13.7 \pm 8.0$ & $853.0 \pm 497.3$ & $61.3 \pm 0.4$ & $0.48 \pm 0.07$ & $23.5 \pm 1.2$ \\
\hline Peat & & $160.0 \pm 21.8$ & $10.3 \pm 2.9$ & $11.7 \pm 4.6$ & $979.7 \pm 235.7$ & $100.0 \pm 50.7$ & $9.3 \pm 1.5$ & $1279.7 \pm 494.7$ & $49.0 \pm 7.2$ & $0.35 \pm 0.04$ & $20.4 \pm 1.0$ \\
\hline Expanded clay & & $144.7 \pm 37.1$ & $9.3 \pm 1.5$ & $8.3 \pm 2.1$ & $483.3 \pm 160.6$ & $63.3 \pm 15.3$ & $8.3 \pm 3.2$ & $1126.7 \pm 559.4$ & $65.1 \pm 1.1$ & $0.56 \pm 0.01$ & $19.6 \pm 1.0$ \\
\hline Vermiculite & & $160.3 \pm 28.7$ & $9.3 \pm 0.6$ & $7.7 \pm 2.9$ & $441.0 \pm 78.6$ & $61.3 \pm 18.6$ & $12.0 \pm 2.6$ & $1136.3 \pm 512.5$ & $60.5 \pm 1.9$ & $0.50 \pm 0.03$ & $20.1 \pm 1.0$ \\
\hline Garden soil & & $154.7 \pm 28.2$ & $6.3 \pm 2.3$ & $4.0 \pm 0.0$ & $189.7 \pm 35.8$ & $39.0 \pm 14.4$ & $7.3 \pm 1.5$ & $488.0 \pm 45.7$ & $64.5 \pm 2.4$ & $0.35 \pm 0.01$ & $18.5 \pm 0.9$ \\
\hline $\begin{array}{l}\text { Perlite } \\
\text { Peat } \\
\text { Expanded clay } \\
\text { Vermiculite } \\
\text { Garden soil }\end{array}$ & Motin & $\begin{array}{c}92.7 \pm 4.6 \\
116.7 \pm 19.6 \\
136.0 \pm 26.9 \\
130.3 \pm 8.7 \\
126.5 \pm 33.2\end{array}$ & $\begin{array}{c}6.7 \pm 1.2 \\
7.3 \pm 1.2 \\
11.0 \pm 2.0 \\
9.7 \pm 1.5 \\
11.5 \pm 0.7\end{array}$ & $\begin{array}{c}10.7 \pm 3.5 \\
16.0 \pm 2.0 \\
10.3 \pm 2.1 \\
11.3 \pm 2.3 \\
6.0 \pm 0.0\end{array}$ & $\begin{array}{c}1205.0 \pm 153.9 \\
1992.7 \pm 238.5 \\
1583.3 \pm 840.1 \\
834.7 \pm 84.0 \\
272.0 \pm 53.7\end{array}$ & & $\begin{array}{c}14.7 \pm 9.3 \\
12.7 \pm 1.2 \\
12.3 \pm 1.2 \\
14.3 \pm 5.1 \\
8.0 \pm 5.7\end{array}$ & $\begin{array}{c}1044.3 \pm 579.6 \\
1639.0 \pm 412.7 \\
929.7 \pm 208.9 \\
1502.7 \pm 763.2 \\
293.5 \pm 200.1\end{array}$ & $\begin{array}{l}52.2 \pm 1.3 \\
38.5 \pm 1.5 \\
49.6 \pm 1.6 \\
45.6 \pm 0.6 \\
57.0 \pm 3.8\end{array}$ & $\begin{array}{l}0.60 \pm 0.03 \\
0.18 \pm 0.02 \\
0.43 \pm 0.04 \\
0.56 \pm 0.03 \\
0.35 \pm 0.11\end{array}$ & $\begin{array}{l}17.2 \pm 0.9 \\
14.5 \pm 0.7 \\
14.4 \pm 0.7 \\
13.7 \pm 0.7 \\
14.7 \pm 0.5\end{array}$ \\
\hline Perlite & Janja & $113.3 \pm 15.3$ & & $8.7 \pm 2.1$ & $744.0 \pm 271.8$ & $126.0 \pm 80.6$ & $19.0 \pm 8.7$ & $1049.3 \pm 575.4$ & $48.8 \pm 2.6$ & $0.43 \pm 0.05$ & $18.4 \pm 0.9$ \\
\hline Peat & & $112.7 \pm 10.8$ & & & $1235.0 \pm 486.3$ & $136.7 \pm 51.1$ & $11.0 \pm 4.6$ & $1634.0 \pm 957.2$ & $36.2 \pm 2.9$ & $0.42 \pm 0.03$ & $15.3 \pm 0.8$ \\
\hline Expanded clay & & $120.7 \pm 9.5$ & & & $738.0 \pm 162.4$ & & $21.7 \pm 7.4$ & $1539.3 \pm 516.7$ & $48.8 \pm 1.3$ & $0.32 \pm 0.02$ & $15.8 \pm 0.8$ \\
\hline Vermiculite & & $142.7 \pm 11.0$ & $9.0 \pm 2.6$ & $10.7 \pm 3.8$ & $716.0 \pm 115.9$ & $69.3 \pm 12.9$ & $18.0 \pm 7.8$ & $1436.0 \pm 225.5$ & $53.4 \pm 4.4$ & $0.27 \pm 0.04$ & $14.9 \pm 0.7$ \\
\hline Garden soil & & $108.3 \pm 17.6$ & $8.7 \pm 1.2$ & $8.0 \pm 4.0$ & $267.0 \pm 49.8$ & $42.7 \pm 10.5$ & $5.0 \pm 2.0$ & $181.3 \pm 115.6$ & $42.9 \pm 0.7$ & $0.43 \pm 0.04$ & $15.2 \pm 0.8$ \\
\hline
\end{tabular}

TPC, total phenolic content; GAE, gallic acid equivalents; FW, fresh weight; AOP, antioxidant potential; TE, Trolox equivalents; AA, ascorbic acid content. Data are expressed as mean \pm standard deviation (n=3). 
in their study on different sweet potato varieties grown in China. As seen in Table 4 significantly higher AA was observed in tubers of sweet potatoes grown in perlite $\left(19.7 \mathrm{mg} 100 \mathrm{~g}^{-1} \mathrm{FW}\right)$, while between varieties significant higher AA was observed in Lučka (20.4 mg 100 $\mathrm{g}^{-1} \mathrm{FW}$ ) (Table 4). These data are higher as reported by Suárez et al. (2016) on thirty sweet potato varieties from Canary Islands, where

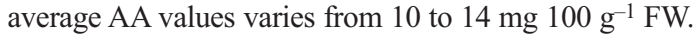

Significant interactions of growing media $($ factor $\mathrm{A}) \times$ variety (factor B) were observed (Table 4) for the following traits: thickness of vinebase, weight of above ground part, AOP, TPC and AA. Interactions showed that different varieties showed different response on growing media (figures not shown). For example, variety Martina had signifi-
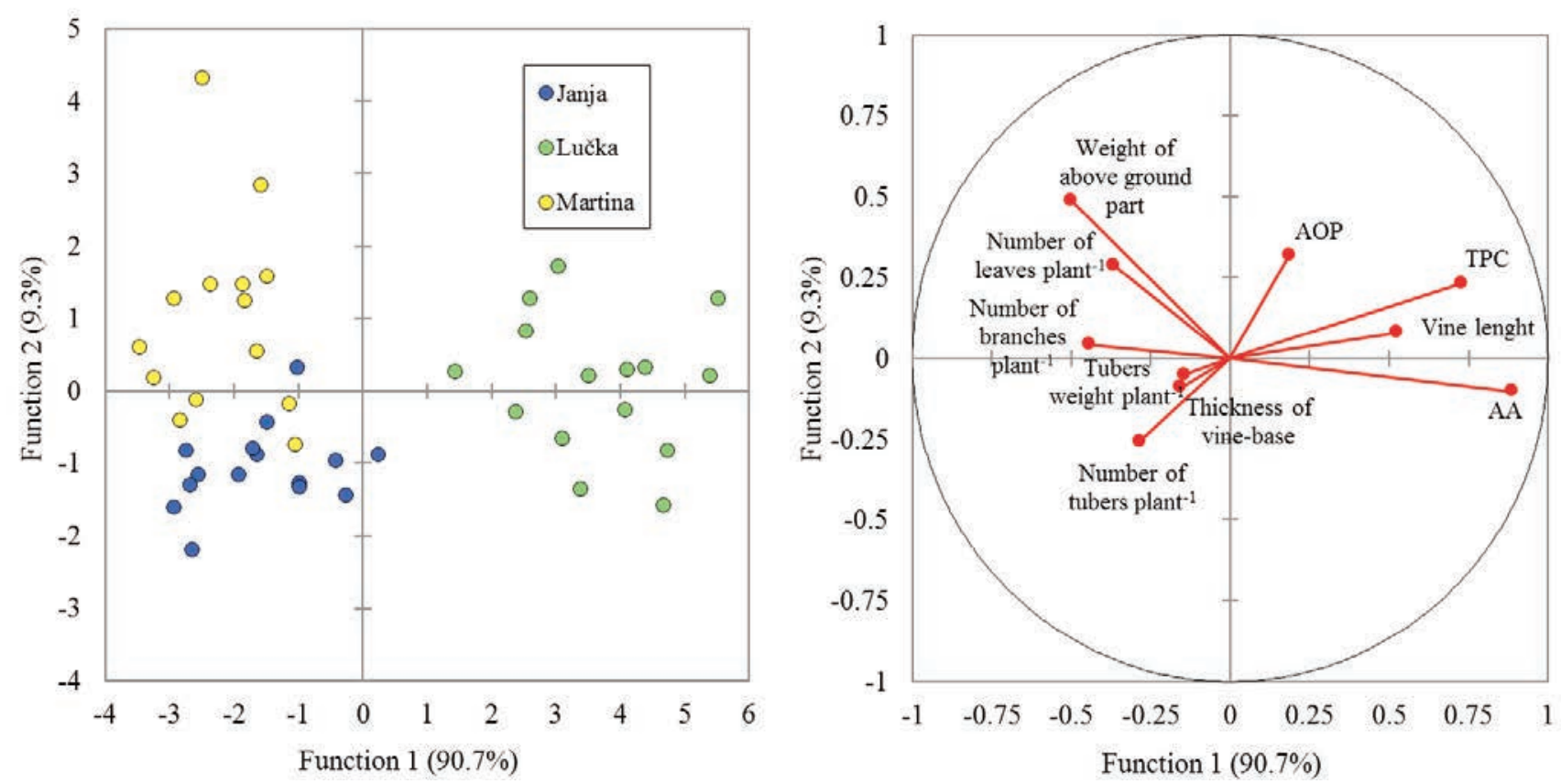

Figure 1. Genetic relationships between varieties applying Nei's genetic distance and unweighted pair group method with arithmetic mean clustering method.
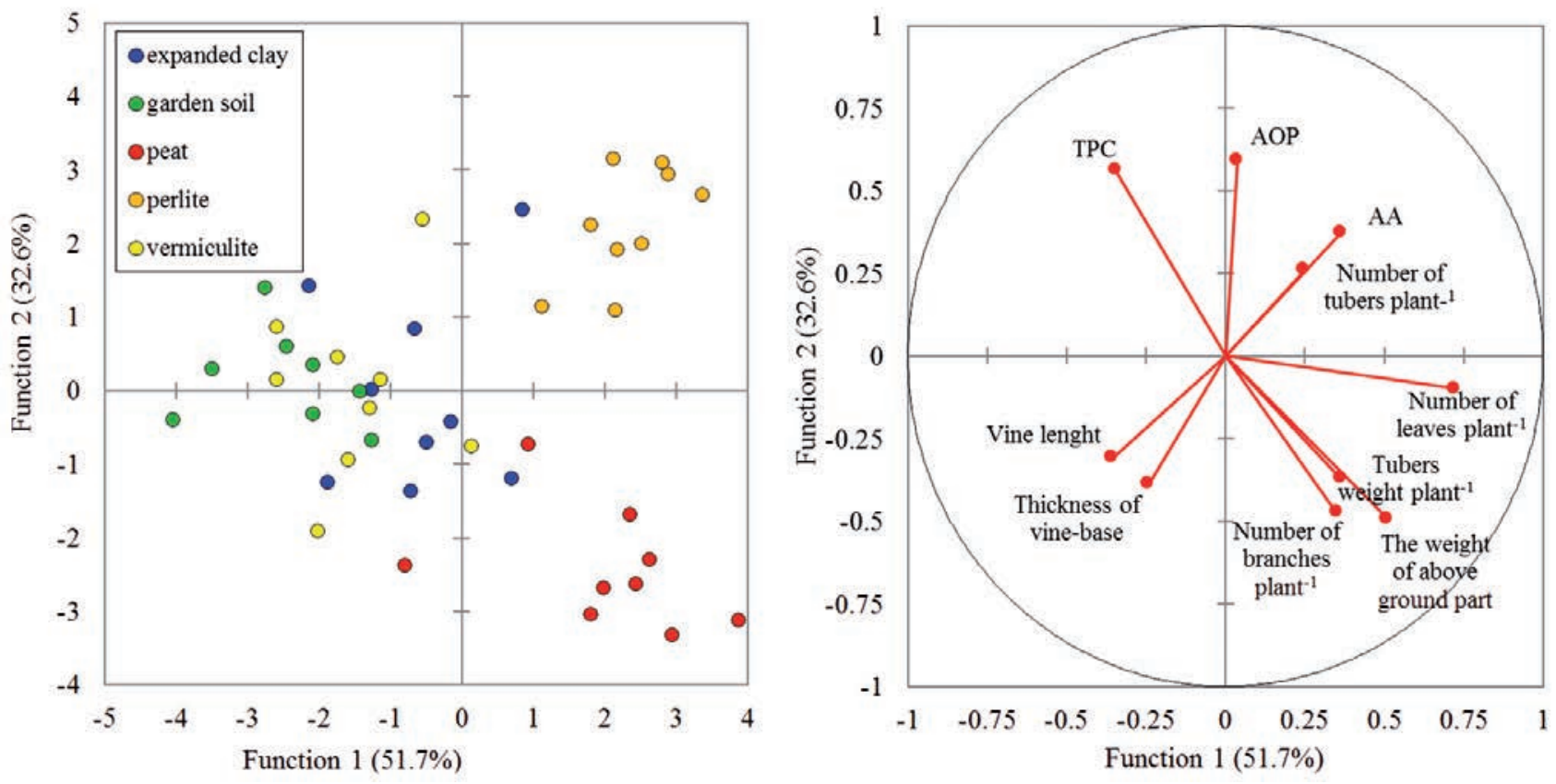

Figure 2. Discriminant analysis plot of observations (left) and variables chart (right) performed with the 10 traits [vine length, thickness of vine-base, number of branches, weight of above ground part, number of leaves plant ${ }^{-1}$, number of tubers plant ${ }^{-1}$, tubers weight plant $^{-1}$, total phenolic content (TPC), antioxidant potential (AOP) and ascorbic acid content (AA)] of the 15 samples originated from 3 sweet potato varieties (Janja, Lučka, Martina). 
cantly higher thickness of vine-base in garden soil, but significantly lowers in peat. However, varieties Janja and Lučka had significantly higher thickness of vine-base in peat, but significantly lower in garden soil. Variety Martina had significantly higher weight of above ground part compared to other varieties in all growing media, except for garden soil. All three varieties showed significantly higher weight of above ground part in peat. Interactions among varieties and growing media showed highly significant differences $(\mathrm{P} \leq 0.001)$ in TPC, AOP and AA. For example, variety Martina had significantly higher TPC in tubers grown in garden soil, while variety Janja lowers. Variety Martina had the lowest AOP in peat, while other varieties did not show response to this growing media. In case of AA all varieties showed similar response in different growing media, except for garden soil.

\section{Multivariate analyses - discriminant analyses}

The discrimination across the original data set of 15 samples originated from 3 sweet potato varieties is shown in Figure 2. Discriminant analysis was carried out across 10 traits: vine length, thickness of vinebase, number of branches, weight of above ground part, number of leaves plant ${ }^{-1}$, number of tubers plant ${ }^{-1}$, tubers weight plant $^{-1}$, TPC, $\mathrm{AOP}$ and AA. The curve defined by the first two discriminant functions (function $1 /$ function 2 ) represents $100.0 \%$ of the total variance for these 10 variables. Function 1 explains $90.7 \%$ of the total variance and function $29.3 \%$ of the total variance. Major contributors to discriminate among different varieties in function 1 are the AA, number of tubers plant ${ }^{-1}$, tubers weight plant $^{-1}$ and vine length, respectively; meanwhile the weight of above ground part, TPC, AOP and number of tubers plant $^{-1}$ are major contributors in function 2 . The groups of the sweet potato varieties Janja, Lučka, Martina were well separated, with the slight overlapping of groups Janja and Martina (one sample of Janja and two of Martina were in the opposite group) (Figure 2). On the basis of discriminant analysis the best varieties from the agronomic point of view were Janja for the traits thickness of vine-base, number of tubers

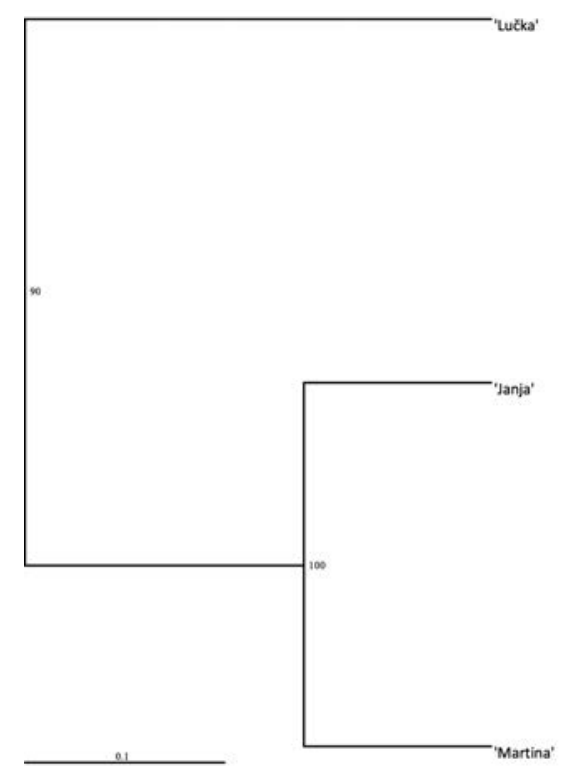

Figure 3. Discriminant analysis of observations (left) and variables chart (right) performed with the 10 traits [vine length, thickness of vine-base, number of branches, weight of above ground part, number of leaves plant ${ }^{-1}$, number of tubers plant ${ }^{-1}$, tubers weight plant ${ }^{-1}$, total phenolic content (TPC), antioxidant potential (AOP) and ascorbic acid content (AA)]. plant $^{-1}$ and tubers weight plant ${ }^{-1}$, and Martina for the traits number of branches, weight of above ground part and number of leaves plant ${ }^{-1}$. The best variety from the nutritional point of view was Lučka for all three investigated parameters (TPC, AOP and AA).

Figure 3 shows the discrimination across the original data set of 15 samples cultivated in 5 different growing media (expanded clay, garden soil, peat, perlite, vermiculite). Discriminant analysis was carried out with the same 10 traits as given above. Function 1 explains $51.7 \%$ of the total variance and function $232.6 \%$ of the total variance. Major contributors to discriminate in function 1 among different growing media are AA, TPC, weight of above ground part and vine length, respectively; meanwhile the number of tubers plant ${ }^{-1}$, TPC, AOP and vine length are major contributors in function 2. As seen from Figure 3 the sweet potato samples grown in garden soil, vermiculite and expanded clay are located close to each other and on the other side of the score plot as those grown in perlite or peat. Sweet potato samples grown in perlite, peat and ganden soil are clearly distinguished among the growing media, while the groups of vermiculite and expanded clay are very scattered into the plot. On the basis of discriminant analysis the best growing media were peat for the traits number of branches, weight of above ground part, number of leaves plant ${ }^{-1}$ and tubers weight plant ${ }^{-1}$, and perlite for the traits number of tubers plant ${ }^{-1}$, AOP and AA.

\section{Conclusions}

The present study investigated the genetic differentiation among three new Slovenian sweet potato varieties (Lučka, Janja, Martina). Results showed that the most genetically diverse variety is Martina. Meanwhile, variety Lučka possess the highest number of alleles which are unique and specific for this variety only. Global genetic variance among all three varieties is $36 \%$. The effect of different growing media (perlite, peat, expanded clay, vermiculite, garden soil) was examined for ten agronomic and nutritional traits of these sweet potato varieties. Overall results show different response of varieties in different growing media. Significant interactions of growing media $\times$ variety were observed for thickness of vine-base, weight of above ground part, AOP, TPC and AA. In conclusion, the discriminant analysis showed that the major traits for distinguishing between sweet potato varieties in function 1 are the AA, number of tubers plant ${ }^{-1}$, tubers weight plant ${ }^{-1}$ and vine length, and in function 2 the weight of above ground part, TPC, AOP and number of tubers plant ${ }^{-1}$; and among growing media in function $1 \mathrm{AA}, \mathrm{TPC}$, weight of above ground part and vine length, and in function 2 the number of tubers plant ${ }^{-1}$, TPC, AOP and vine length.

\section{References}

Belkhir K, Borsa P, Goudet J, Bonhomme F, 1999. Genetix: logicel sous Windows pour la génétique des populations, Version 4.02. Université de Montpellier II, Laboratoire Genome, Populations, Interactions, Montpellier, France. Available from: http://kimura. univ-montp2.fr/genetix/

Bovell-Benjamin AC, 2007. Sweet potato: a review of its past, present, and future role in human nutrition. Adv. Food Nutr. Res. 52:1-59.

Buteler MI, Jarret RL, LaBonte DR, 1999. Sequence characterization of microsatellites in diploid and polyploid Ipomea. Theor. Appl. Genet. 99:123-32.

Chandrasekara A, Kumar TJ, 2016. Roots and tuber crops as functional foods: a review on phytochemical constituents and their potential health benefits. Int. J. Food Sci. 2016:1-15. 
Derlink M, Pipan B, Pavlovčič P, Jones LE, Meglič V, Symondson WOC, Virant-Doberlet M, 2014. Characterization of eleven polymorphic microsatellite markers for leafhoppers of the genus Aphrodes (Hemiptera: Cicadellidae). Conserv. Genet. Resour. 6:933-5.

FAOSTAT, 2017. Food and agricultural statistical database. Available from: http://faostat.fao.org

Jankauskienė J, Brazaitytė A, Viškelis P, 2015. Effect of different growing substrates on physiological processes, productivity and quality of tomato in soilless culture. In: Md. Asaduzzaman (Ed.) Soilless culture: Use of substrates for the production of quality horticultural crops. InTech, Rijeka, Croatia, pp. 99-124.

Jung JK, Lee SU, Kozukue N, Levin CE, Friedman M, 2011. Distribution of phenolic compounds and antioxidative activities in parts of sweet potato (Ipomoea batata L.) plants and in home processed roots. J. Food Comp. Anal. 24:29-37.

Kunstelj N, Žnidarčič D, Šter B, 2013. Employing artificial neural networks and regression in analysis on knowledge about sweet potato (Ipomoea batatas L.) in Slovenia. Ital. J. Food Sci. 25:263-74.

Kunstelj N, Žnidarčič D, Šter B, 2015. Using association rules mining for sweet potato (Ipomoea batatas L.) in Slovenia: a case study. J. Food Agric. Environ. 11:253-8.

Langella O, 2002. Population 1.2.28. Logiciel de génétique des populations. Laboratoire Populations, Gif-sur-Yvette, France.

Lebot V, Michalet S, Legendre L, 2016. Identification and quantification of phenolic compounds responsible for the antioxidant activity of sweet potatoes with different flesh colours using high performance thin layer chromatography (HPTLC). J. Food Comp. Anal. 49:94-101.

Maras M, Pipan B, Šuštar-Vozlič J, Todorović V, Đurić G, Vasić M, Kratovalieva S, Ibusoska A, Agić R, Matotan Z, Čupić T, Meglič $\mathrm{V}, 2015$. Examination of genetic diversity of common bean from the Western Balkans. J. Amer. Soc. Hort. Sci. 140:208-316.

Mukhtar AA, Tanimu B, Arunah UL, Babaji BA, 2010. Evaluation of the agronomic characters of sweet potato varieties grown at varying levels of organic and inorganic fertilizers. Int. J. Organic Agric. Res. Develop. 1:83-91.

Nakajima JI, Tanaka I, Seo S, Yamazaki M, Saito K, 2004. LC/PDA/ESI-MS profiling and radical scavenging activity of anthocyanins in various berries. J. Biomed. Biotechnol. 5:241-7.

National List of Varieties, 2016. Republic of Slovenia, Ministry of Agriculture, Forestry and Food, The administration of the Republic of Slovenia for Food Safety, Veterinary Sector and Plant Protection. Available from: http://www.uvhvvr.gov. si/fileadmin /uvhvvr.gov.si/pageuploads/OBJAVE_ZA_JAVNOST/Objave_S EME/Sortna lista/SL 2015 splet.pdf

Oki T, Masuda $\bar{M}$, Furuta S, Nishiba Y, Terahara N, Suda I, 2002. Involvement of anthocyanins and other phenolic compounds in radical-scavenging activity of purple-fleshed sweet potato cultivars. J. Food Sci. 67:1752-6.

Padda MS, Picha DH, 2008. Quantification of phenolic acids and antioxidant activity in sweetpotato genotypes. Sci. Hort. 119:17-20.

Page RDM, 1996. TREEVIEW: an application to display phylogenetic trees on personal computers. Comput. Appl. Biosci. 12:357-8.

Peakall R, Smouse PE, 2006. GENALEX 6: genetic analysis in Excel. Population genetic software for teaching and research. Mol. Ecol. Notes 6:288-95.

Pipan B, Šuštar-Vozlič J, Meglič V, 2011. Cultivation, varietal structure and possibilities for cross-pollination of Brassica napus L. in Slovenia. Acta Agic. Slov. 97:247-58.

Pipan B, Šuštar-Vozlič J, Meglič V, 2013. Genetic differentiation among sexually compatible relatives of Brassica napus L. Genetika 45:309-27.

Pipan B, Žnidarčič D, Kunstelj N, Meglič V, 2017. Genetic evaluation of sweet potato accessions introduced to the central European area. J. Agric. Sci. Technol. 19:1139-50.

Pipan B, Žnidarčič D, Meglič V, 2016. Evaluation of genetic diversity of sweet potato [Ipomoea batatas (L.) Lam.] on different ploidy levels applying two capillary platforms. J. Hort. Sci. Biotechnol. 92:192-8.

Quirós ARB, Fernández-Arias M, López-Hernández J, 2009. A screening method for the determination of ascorbic acid in fruit juices and soft drinks. Food Chem. 116:509-12.

Ray RC, Panda SK, Swain MR, Sivakumar PS, 2012. Proximate composition and sensory evaluation of anthocyanin $\square$ rich purple sweet potato (Ipomoea batatas L.) wine. Int. J. Food Sci. Tech. 47:452-8.

Roura E, Andrés-Lacueva C, Estruch R, Lamuela-Raventós RM, 2006. Total polyphenol intake estimated by a modified Folin-Ciocalteu assay of urine. Clin. Chem. 52:749-52.

Rumbaoa RGO, Cornago DF, Geronimo IM, 2009. Phenolic content and antioxidant capacity of Philippine sweet potato (Ipomoea batatas) varieties. Food Chem. 113:1133-8

Rusjan D, Pelengić R, Pipan B, Or E, Javornik B, Štajner N, 2015. Israeli germplasm: phenotyping and genotyping of native grapevines (Vitis vinifera L.). Vitis 54:87-9.

Rusjan D, Pipan B, Pelengić R, Meglič V, 2012. Genotypic and phenotypic discrimination of grapevine (Vitis vinifera L.) varieties of the 'Vitovska' and 'Garganja' denominations. Eur. J. Hortic. Sci. 77:84-94.

Schuelke M, 2000. An economic method for the fluorescent labeling of PCR fragments. Nat. Biotechnol. 18:233-4.

Shekhar S, Mishra D, Buragohain AK, Chakraborty S, Chakraborty N, 2015. Comparative analysis of phytochemicals and nutrient availability in two contrasting cultivars of sweet potato (Ipomoea batatas L.). Food Chem. 173:957-65.

Singleton VL, Rossi JA, 1965. Colorimetry of total phenolics with phosphomolybdic phosphotungstic acid reagents. Am. J. Enol. Viticult. 16:144-58

Suárez MH, Hernández AIM, Galdón BR, Rodríguez LH, Cabrera CEM, Mesa DR, Rodríguez-Rodríguez EM, Romero CD, 2016. Application of multidimensional scaling technique to differentiate sweet potato (Ipomoea batatas (L.) Lam) cultivars according to their chemical composition. J. Food Comp. Anal. 46:43-9.

Tang Y, Cai W, Xu B, 2015. Profiles of phenolics, carotenoids and antioxidative capacities of thermal processed white, yellow, orange and purple sweet potatoes grown in Guilin, China. Food Sci. Human Wellness 4:123-32.

Teow CC, Truong VD, McFeeters RF, Thompson RL, Pecota KV, Yencho GC, 2007. Antioxidant activities, phenolic and $\beta$-carotene contents of sweet potato genotypes with varying flesh colours. Food Chem. 103:829-38.

Veasey EA, Borges A, Silva Rosa M, Queiroz-Sila JR, de Andrade Bressan E, Peroni N, 2008. Genetic diversity in Brazilian sweet potato (Ipomoea batats (L.) Lam., Solanaes, Convolvulaceae) landraces assessed with microsatellite markers. Genet. Mol. Biol. 31:725-33. 